\title{
Around the World with United States Libraries
}

Mrs. Wessells is acting chief, Division of Libraries and Institutes, U.S. Department of State.

$\mathrm{M}$

ORE THAN IOO United States libraries and reading rooms throughout the world are making available to the peoples of other countries accurate information about the U.S. American books, periodicals, newspapers, pamphlets, music and films all help to tell the people of the world what America is like, how it operates, how it thinks, and why it sometimes acts as it does in world affairs. The culture of America -as expressed through literature, music, films and other materials which give a true account of the progress of the people of the U.S., their present problems and their plans for the future of the country-is being made known to other countries, as well as American know-how in industry, science, and technology.

Beginning with the U.S. Library in London, established in 1942 by the Office of War Information, the American library movement abroad rapidly spread, with libraries opening shortly thereafter in Sydney, Melbourne, Wellington, Bombay, and other cities. Today it is truly a global operation.

In 1948, Public Law 402 (the SmithMundt Act) established U.S. libraries on a firm foundation, and they appear to have won Congressional approval. The congressmen and senators who have seen the libraries in action in Europe, the Near East, Latin America, Australia and other parts of the world, have expressed approval of a service which is to the credit of the U.S. Although U.S. library collections are limited to American books, music, films and materials portraying the American scene, their services are available to all the people of the host country to make use of them in any way in which the know-how of the U.S. may be applied. The libraries present America as it is, with its good and bad traits, but they let foreign peoples know that America is making an earnest effort to solve her problems, to overcome the situations in regard to housing, education and social questions of all sorts, and that the U.S. has much to offer in the field of the humanities.

\section{Basic Pattern}

Wherever U.S. libraries are located-in Italy, France or elsewhere in Europe, China, Burma, Egypt, New Zealand, Australia, Latin America or in countries behind the Iron Curtain-they follow the same basic pattern with essential variations to meet local conditions: Each library has a basic collection of reference materials about the U.S., a small collection of periodicals, a good selection of U.S. Government documents and pamphlets, and as soon as possible an American librarian to help in the use of the material. The growth of each library depends upon the community and the national interests of the country in which it is located, each collection being tailor-made insofar as practicable to the specific interests of its readers. In any 
case the structure remains small and highly specialized, a functional unit, designed to give quick and accurate service in disseminating information about America to news and radio people, foreign government officials, educational and cultural institutions, and the man on the street. Work with cultural leaders, government officials and business and professional people goes on constantly; work with students and young people is an important facet of the program. Service for children is being developed in many parts of the world, particularly in those countries where English language teaching begins at the elementary or junior high school level.

The universities and colleges in the cities and countries in which U.S. libraries are located have used the facilities of the libraries since their beginning. During the war, as the Philippines were liberated and the U.S. Library in Manila was established, an American foreign service officer in charge was able to engage several librarians from the University of the Philippines Library. Their building was destroyed and their collections badly damaged, but the background of these librarians and their know-how helped to establish a specialized American library service - small at first, and serving a limited group, but now expanded to the point where the main U.S. Library in Manila is also responsible for the operation of branches at Iloilo, Cebu and Davao. Without the aid of these Filipino librarians, it would have taken longer to establish the library, to follow through with assistance to library service in the country, aid to library associations and to the rehabilitation of existing services. The only library reference services available to students and teachers in Cebu and Iloilo at present are those offered by the U.S. Libraries. The Iloilo branch reports the wide influence of American professional literature and extensive demands for books on education-its history, philosophy and psychology, and books on science and the vocational trades. In Manila, the U.S. Library has cooperated with the University of the Philippines in many ways, including special loan collections on a long-term basis and the donation of hundreds of Army surplus books to the university library.

In 1947 , when through a drastic economy program a number of operations were closed or limited in scope, the reaction of the people in the countries affected was spontaneous. In Melbourne, for instance (and the same story could be told for other places), the head of the history department of the University of Melbourne came to the U.S. Library with the question which had been asked by everyone: "Is it true?" When assured that it was true that the library would close its doors, he said that it just could not be done, because the university was planning a course in American history for which it hoped to have American professors as visiting lecturers, and that the books in the library were absolutely essential in developing the course. In Australia, as in other sterling areas, the importation of American books was subject to restrictions and prohibitions, and the loss of current materials would prove to be a serious blow. The university council offered to build a temporary building on the overcrowded campus to house the collection and to keep it available, not only to the people of Melbourne but to the faculty and students of the university. Fortunately an arrangement was made whereby the collection was housed as a unit by the Public Library of Victoria and the Australian staff of the library was retained. Their salaries were paid by the Victorian State Government. Similar reactions came from universities in other countries. Commerce departments, science, arts and other university depart- 
ments used the U.S. Library collections to supplement their university library stock and to get the American viewpoint. An architect about to plan and build a new university library studied the books on library architecture in one U.S. Library and then, with the aid of the librarian, plotted an American itinerary which would enable him to see examples of modern library planning. The plans have now developed to the stage where the university library will be constructed. The drama group in another university used the library materials constantly for their productions of modern drama, beautifully staged and capably acted; books from the library provided accurate material on costuming - even on how to dress a postman, on historical settings and on lighting. American newspapers sent by air were used as props. In one country an exhibit of children's art provided wall hangings for stage settings for a commercial showing of the Voice of the Turtle, which had a run of many weeks.

Educational films are shown in many U.S. Libraries as a part of their information activity, and the universities of many countries have utilized the film collections. Students of agriculture in every country of the world have seen the film $T V A$, as have ministers of agriculture, department staffs and people attending extension courses far from film centers. U.S. documentary films are circulated widely in most countries, mobile units being used in some cases to go far into the interior with projectors and films. Plans are being developed to include bookshelves in these mobile units in order to give bookmobile service, with material illustrating the films, or just good material about America for the use of people who may not be able to go to the library.

Mail service for answering requests for information about America is part of the service of every U.S. Library. Loan serv- ices are being developed to supplement written answers to requests. Universities are apt to be the recipients of loan collections designed to add American information to the university library collection. Secondary schools may also receive package library service to aid in courses on geography, to highlight history courses (which in some cases relegate the U.S. to a few paragraphs in a textbook), and to enliven English language study. Now books which live and which make the people of the U.S. live are available to aid educationalists, as is information about educational activities for ministries of education. College catalogs form a part of each library's collection, and other educational materials are provided on request. U.S. Government documents are a major source of information for the use of library readers and it is amazing to discover how many people from other countries know more about U.S. Congressional bills, conferences, and similar information than do many Americans. Materials on government and procedures have been used by many new republics in setting up their own constitutions and governments; the Vermont state constitution was used as a sample by one Indian governor.

The Division of Libraries and Institutes of the Department of State is the channel through which the flow of information concerning education in the U.S. is made available to other countries, and through which American persons and institutions are informed of educational developments abroad. Collections of representative American textbooks, at college and university as well as elementary and secondary levels, plus teachers manuals, professional literature, books and other materials which will present American educational methods and standards to foreign educators and officials, are provided through U.S. Foreign Service establishments in every country. These care- 
fully selected educational collections are widely used by ministries of education, textbook publishers and educators interested in curriculum revision in the countries in which the collections are deposited.

Medical collections and collections of American books on law are available through the U.S. Libraries in many countries.' During the war years, the American library was often the only place where information could be obtained on up-to-date methods of treating war injuries, new drugs, and medical progress in general. Collections of medical books have grown in response to public demands, and in some countries are on loan to medical schools to supplement existing book collections. In most cases they are housed with the U.S. Library. Special collections of law books have been sent to Liberia, Israel and other countries. The Monrovia (Liberia) U.S. Library recently reported the receipt of its collection on law, commenting as follows:

A special reading corner for lawyers was set up, where readers may browse, read and take notes, as the collection is entirely reference material. An announcement of this service was sent out through the Weekly News Bulletin and many lawyers, as well as students from the law classes of Liberia College, have come in and made use of the collection. ... Liberia (and more specifically Monrovia) is going through a period of construction. We feel the impact of this period in the library from the constant demand for books on engineering and building construction. . . . We are beginning to feel other trends of popular interest, which may also be traced to community problems. There has been a growing interest in electricity; specifically, our calls have been more for wiring and installation; more recent demands are for books on banking and accounting.... The director of the teacher training program for Liberia has acquainted us with a required reading program for his classes. Teachers at the College of West Africa have begun assigning outside work which is reflected in demands upon the United States Library, and we often find ourselves rushed for information on such fa- miliar subjects as the Norman Conquest, Shakespeare's England, the story of leather, and the like.

In the so-called backward areas of the world, the problem of assisting the national educational authorities to improve their educational systems is especially challenging, since the economic and social development of the countries concerned is dependent upon better education for all citizens. Wherever the need exists, the United States Libraries offer all the help possible, such as is being given in the countries mentioned below :

Nigeria's new adult education program, sponsored by Ibadan University College, is being assisted through long-term loans of books on such subjects as agriculture, public health, education, sociology, economics, history and social work; U.S. Government documents and periodicals are also included. As the program gets under way in the fall of 1949 , it is planned to supply additional books and publications which may be needed, based upon the experience of the educators in charge of the program.

Supplementary American text materials for schools in Afghanistan will be available during the coming year through long-term loan collections. Since English is not widely known in Afghanistan, this material will be carefully selected for simplicity of presentation. Other long-term loan collections will be circulated to schools in the Belgian Congo, Siam, Burma and Kenya.

The University of Rangoon is receiving from the U.S. Library back issues of many scientific journals, such as the Journal of the American.Medical Association, in order to make them more easily available to the students - and at the same time to ease the storage problem of the library.

The Pakistan Ministry of Education is studying the American school system, its history and development, the results to be used in reorganizing the elementary and sec- 
ondary school system of the country. A U.S. Library was opened in Karachi during the summer of 1949 , which will make American books and other publications readily available to the people of this new nation.

In India, Egypt and other countries, there is interest in the functioning of American student organizations as a uniquely American agency through which students can solve some of their academic and campus problems, and at the same time learn to assume responsibility for governing themselves.

Iran is one of several countries which have requested books and materials which would enable the Ministry of Education to comprehend and adapt the philosophy and methods of American schools to the needs of the country concerned.

The U.S. Library at Ankara, Turkey, which is used extensively by students and professors of the University of Ankara, the Agricultural College and the Teachers College, has provided source material to a Turkish author who is writing a book on "The University Movement in America."

A collection of books on tuberculosis control and related subjects has been recently supplied to the U.S. Library at Rangoon, for the use of the Government of Burma in its general program of combatting tuberculosis.

The Delhi, India, School of Economics has recently acquired from the State Department a collection of American books covering advanced economics, labor economics, public finance, economics of planning, economic statistics and administration, selected by the school's director in consultation with the staff of the Division of Libraries and Institutes and officials of the Library of Congress.

In the Far East, I I U.S. Libraries in China have provided textbooks and numerous educational services to universities and schools. The Chungking U.S. Library recently reported that it had 12 circulating collections on loan to institutions as follows: two colleges; two hospitals; one chemical research institute; one electric factory; five middle schools; one government organization. Included in these collections were 530 books, 2700 magazines, 1650 U.S. Government documents and pamphlets and 2 Io newspapers. American publications were thus made available to and used by 148 professors, 825 college students, 472 high school teachers, 2 roo middle school students, 332 medical people, 460 engineers and research workers and 570 government employees. This library supplies special loans of technical materials to the West China Science Institute for its research staff, and sends rural educational materials for the use of the Rural Reconstruction College at Hsuih-Ma-Chang. A traveling bookcase is used by the Chungking Library to circulate books to colleges and schools. The Shanghai U.S. Library recently delivered to Soochow University three cases of books donated by the American Library Association, and 600 back numbers of technical periodicals to St. John's University. Central University Teachers College is initiating an audio-visual program using U.S.I.E. films and filmstrips, and supplementary reading material.

A cleavage in the interests of the people of western Europe and those of eastern Europe is reflected in the demands made upon U.S. Libraries. In the Iron Curtain countries, great interest is evinced in scientific and industrial developments in the U.S., due probably to the dearth of readily available data from other sources-the U.S. Library being one of the few sources for such information. In the free countries of Europe there is broader, more normal use of the U.S. Libraries, with evidences of interest in American literature, history and govern-

(Continued on page 35I) 
the National Library collect and publish statistics on libraries, that archival materials be collected systematically and cataloged, and that national subject bibliographies be made and published. Actually, much effective work remains to be done within individual libraries themselves before the broader problems can be attacked effectively, and other improvements require international rather than national action. The recent Assembly of Librarians of the Americas was a most auspicious step toward international cooperation.

\section{Conclusion}

Several broad conclusions regarding university libraries in South America may be drawn from this experience. In general, the libraries are just entering upon the stage of professional development and much progress is now being made with much more still to come. Many of their problems arise from this condition, but there are other and perhaps more serious difficulties that can be solved only by international cooperation in which U.S. librarians should take a part. All relations with these libraries must take into consideration their own special problems; it must not be assumed that they are exact counterparts of North American university libraries, and they never will be. Finally, the keystone to successful relations is sympathetic understanding - this is far more important than merely being able to speak their language - and can hardly be stressed sufficiently.

\section{Around the World with U. S. Libraries}

(Continued from page 325)

ment, as well as in the scientific and technological fields.

Schools and universities in some of the communist controlled countries avail themselves of the opportunity to obtain American books and magazines for the use of students and teachers. A collection of U.S. textbooks and readers recently made available to schools in one satellite country is reported to be serving dozens of classes in English language study. The themes of these carefully selected books are life in the U.S. and how democracy works. American librarians have been active in helping these overseas U.S. libraries to become the exciting places that they are-librarians from public libraries, special libraries, university libraries and the Library of Congress have all been in the field. Flora Belle Ludington, Wallace Van Jackson, Winifred Lindeman and many others have aided in the establishment of libraries which are worthy of praise. For openings in these libraries, the personality and professional re- quirements are high and the language qualifications stringent. The need is for men and women with professional training and broad experience, who have the ability to cut red tape and to operate efficiently with a skeleton staff of alien employees. The recruitment of such librarians is obviously difficult. To work as a part of a team, with the mission, with specialists in information, news, radio, and cultural activities; to know America thoroughly, but to be aware of the sensibilities of the people of the country in which one works; to know all levels of people; to have the ability to defend America through speeches and through quiet actions when occasion demands; to be never a passive citizen, but always actively to represent America-these responsibilities are not easy, in a strange land, with strange customs, with tools and equipment missing when most needed. But those librarians who have been with the U.S.I.E. program somehow believe in it and come back to work for it whether abroad or in the U.S. 